\title{
Effects of estrone on the early life stages and expression of vitellogenin and estrogen receptor genes of Japanese medaka (Oryzias latipes)
}

\author{
Bingli Lei ${ }^{\mathrm{a}, *}$, Yu Wen ${ }^{\mathrm{a}}$, Xuetong Wang ${ }^{\mathrm{a}}$, Jinmiao Zha ${ }^{\mathrm{b}}$, Wei Li ${ }^{\mathrm{b}}$, Zijian Wang ${ }^{\mathrm{b}}$, Yanfeng Sun ${ }^{\mathrm{a}}$, Jia Kang ${ }^{\mathrm{a}}$, \\ Yipei Wang ${ }^{\mathrm{a}}$ \\ a Institute of Environmental Pollution and Health, College of Environmental and Chemical Engineering, Shanghai University, Nanchen Rd 333, Baoshan District, Shanghai 200444, \\ PR China \\ ${ }^{\mathrm{b}}$ State Key Laboratory of Environmental Aquatic Chemistry, Research Center for Eco-Environmental Sciences, Chinese Academy of Sciences, Beijing 100085, PR China
}

\section{H I G H L I G H T S}

- We evaluate effect of E1 on the early life stage of Japanese medaka.

- EI affected hatchability, time to hatching and the growth, deteriorated development.

- E1 changed ER $\alpha$ and Vtg-I gene mRNA levels of both sexes at low concentrations.

- E1 has unrecoverable impacts on medaka, even if only early life stages were exposed.

\section{A R T I C L E I N F O}

\section{Article history:}

Received 12 January 2013

Received in revised form 16 April 2013

Accepted 2 June 2013

Available online 3 July 2013

\section{Keywords:}

Estrone

Early life stage

Vitellogenin gene

Estrogen receptor gene

Oryzias latipes

Water recovery group

\begin{abstract}
A B S T R A C T
The fertilized eggs of Japanese medaka (Oryzias latipes) were exposed to estrone (E1) at 5-5000 ng $\mathrm{L}^{-1}$ for $15 \mathrm{~d}$, and the hatched fry were exposed continuously to the same concentrations for the additional $15 \mathrm{~d}$.

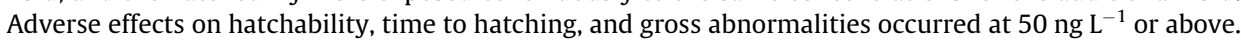
Then the fry were divided into a continual exposure group, and a water recovery group. When the fry were exposed to E1 for another $60 \mathrm{~d}$, there was a decrease in the hepatosomatic index (HSI) of males and the influence disappeared in the water recovery group. The gonadosonatic index (GSI) of females at $500 \mathrm{ng} \mathrm{L}^{-1}$ decreased significantly in another 60 d exposure. While the fry were maintained in dechlorinated tap water for $60 \mathrm{~d}$, a significant decrease in female GSI was observed at $50 \mathrm{ng} \mathrm{\textrm {L } ^ { - 1 }}$ or above. An increased GSI was found in males in both continual exposure and water recovery groups at all E1 treatments. Quantitative RT-PCR showed that vitellogenin-I (Vtg-I) gene expressions in the female liver were significantly down-regulated at $50 \mathrm{ng} \mathrm{L}^{-1}$ in the continual exposure group, and at $500 \mathrm{ng} \mathrm{L}^{-1}$ in the water recovery group, while male VtgI genes were significantly up-regulated for all E1 treatments. In addition, all E1 treatments caused sex reversal of males. These results suggest that $\mathrm{E} 1$ at $5 \mathrm{ng} \mathrm{L}^{-1}$ or above have unrecoverable impacts on the gonadal growth and development of medaka, even if only early life stages were exposed to E1.
\end{abstract}

(C) 2013 Published by Elsevier Ltd.

\section{Introduction}

Steroid hormones in the aquatic environment originate mainly from domestic sewage, and the effluents from wastewater treatment plants and agriculture (Hanselman et al., 2003). Steroidal estrogens are a potent subset of steroid hormones, and based on their origin can be characterized as either natural (for example, estrone [E1]) or synthetic (for example, ethinylestradiol [EE2]). They play important roles in the reproductive biology of vertebrates and have the ability to bind and activate estrogen receptors, thereby inducing endocrine responses that may cause reproductive impairment (Jobling and Tyler, 2003; Dammann et al., 2011). Numerous

\footnotetext{
* Corresponding author. Tel.: +86 21 66137734; fax: +86 2166136928 .

E-mail address: leibingli@shu.edu.cn (B. Lei).
}

studies have reported adverse effects when fish were exposed to low concentrations of steroidal estrogens. These effects include increased plasma vitellogenin concentrations in males, increased rates of intersex, altered behavioral responses and decreased reproductive success (Panter et al., 1998; Imai et al., 2007; Zha et al., 2008; Sun et al., 2009; Hyndman et al., 2010). In particular, feminization of male fish due to long term exposure to low concentrations of steroids in aquatic environments has caused great concern throughout the world (Vethaak et al., 2005; Randak et al., 2009; Lu et al., 2011). On an ecological scale, exposure to environmentally relevant concentrations of steroidal estrogens can lead to decreased sustainability of fish populations (Kidd et al., 2007; Palace et al., 2009; Lange et al., 2011).

$17 \beta$-Estradiol (E2) can be metabolized or degraded to E1 (Stumpe and Marschner, 2009), which is often found at higher 
concentrations than E2 in an aquatic environment (Lei et al., 2009). However, E1 is assumed to be less potent than E2 at similar concentrations. For example, Van den Belt et al. (2004) utilized a combination of in vitro and in vivo assays to determine estrogenic potencies across a range of concentrations at or above environmental concentrations. It was found that E1 had half the potency of E2 for causing ovarian somatic index reduction. Panter et al. (1998) found that E2 exposure resulted in greater plasma vitellogenin concentrations than a similar amount of E1. Therefore, there are many studies focusing on the estrogenic effects of E2 on fish. In contrast to E2, there is still a lack of data on the biological effects of E1 on fish (Dammann et al., 2011; Caldwell et al., 2012), even though the aquatic concentrations of E1 are often higher than those of E2 (Williams et al., 2003; Lei et al., 2009). E1 has been detected in natural rivers of many countries at concentrations of 0.8-3.9 ng L ${ }^{-1}$ from France (Cargouët et al., 2004), 0.3-7.2 ng L from The Netherlands (Vethaak et al., 2005), 0.37-10 $\mathrm{ng} \mathrm{L}^{-1}$ from Belgium (Noppe et al., 2007), 1.3-9.2 ng L ${ }^{-1}$ from Germany (Hintemann et al., 2006), and $0.64-20.2 \mathrm{ng} \mathrm{L}^{-1}$ from China (Lei et al., 2009). However, in such environmental concentrations, it is not known whether growth, development and reproduction of aquatic organisms such as fish are affected.

The objective of this study, therefore, was to evaluate the effects of E1 on embryonic development, sex differentiation, growth and reproduction of Japanese medaka (Oryzias latipes) after exposure to E1 at different concentrations including one environmentally relevant concentration. At the same time, to evaluate the effects of exposure of E1 on early life stages and future growth and reproduction of these fish, a water recovery experiment was set up. The entire exposure time was $90 \mathrm{~d}$ and the corresponding endpoints including time to hatching, hatchability, sex ratio, gross abnormalities, hepatosomatic index (HSI) and gonadosomatic index (GSI) were measured. The underlying estrogenic mode of action (MoA) of E1 was evaluated by transcriptional expression of both Vtg-I and $\mathrm{ER} \alpha$ genes at various concentration levels.

\section{Materials and methods}

\subsection{Test chemicals and fish}

Estrone (E1) was purchased from Sigma-Aldrich, USA (purity is 99\%). The different concentrations of E1 stock solutions were prepared with HPLC-grade DMSO. All the other chemicals were analytical or HPLC grade. The exposure concentrations of E1 presented in this study are nominal concentrations of E1. Lucas and Jones (2006) reported that the half-life time of E1 in three soils after addition in distilled water ranged from 4.7 to $24.8 \mathrm{~d}$, and the half life time of E1 was longer than that of E2 in soils (Collucci and Topp, 2001). The half life time of E1 degradation in waters cannot be obtained from the literatures that we can find. However, degradation studies carried out in waters from five English rivers in ideal summer temperatures indicated that E2 has a half life time of 3-27d (Kuster et al., 2004). If the half life time of E1 was also longer than that of E2 in rivers, the half life time of E1 should be more than 3-27 d. Therefore, the real concentrations of $\mathrm{E} 1$ in the exposure experiments of the study were not measured. However, to ensure relatively stable concentration of E1 in the exposure experiment, the exposure solution was renewed every $24 \mathrm{~h}$.

Medaka is an appropriate model species for evaluating reproduction and has already been used in many types' reproductive tests. In this study, Japanese medaka (d-rR strain) fish were kindly provided by Y. Wakamatsu (Laboratory of Freshwater Fish at the Bioscience Center of Nagoya University, Japan). The brood stock has been maintained in our laboratory for more than
4 years. Medaka were kept in charcoal-dechlorinated tap water (pH 7.2-7.6; hardness 44.0-61.0 $\mathrm{mg} \mathrm{CaCO}_{3} \mathrm{~L}^{-1}$ ) at a constant temperature $\left(25 \pm 1{ }^{\circ} \mathrm{C}\right)$ with a photoperiod of $16: 8 \mathrm{~h}$ (light:dark). The brood stock was fed three times daily, once with newly hatched brine shrimp (Artemia nauplii) and twice with commercial food (TetraMin ${ }^{\circledR}$, Germany) at a rate of $0.1 \%$ body weight of fish per day.

\subsection{Exposure and experimental design}

At the early life stage, embryos less than $4 \mathrm{~h}$ post-fertilization were used in the exposure experiments. Spawned eggs were carefully collected from the ventral side of stock females (about 80 females) within a few hours of natural fertilizations. Egg clutches were separated by gently rolling them with a finger. Eggs were disinfected by placing them in a $0.9 \%$ solution of hydrogen peroxide for $10 \mathrm{~min}$ (Marking et al., 1994; Sun et al., 2007), and then checked for fertilization using a dissecting microscope. For each exposure level, 180 embryos were randomly separated into three equal groups (i.e. triplicate groups/exposure). Embryos were exposed to nominal E1 concentrations of $5,50,500$ and $5000 \mathrm{ng} \mathrm{L}^{-1}$ in dilution water containing $1 \%$ methylene blue for $15 \mathrm{~d}$. In addition, solvent controls (SC) containing $0.1 \%$ DMSO and $1 \%$ methylene blue were included in the experimental design. 60 embryos in each group were placed in a glass dish containing $150 \mathrm{ml}$ of each test solution and incubated on a 16:8 h light:dark photoperiod cycle at $25 \pm 1^{\circ} \mathrm{C}$. Eighty percent of the test solution and SC was renewed every $24 \mathrm{~h}$. Embryos were observed twice daily at which time dead embryos (identified by the incorporation of methylene blue) were removed. Hatchability, time to hatching and gross abnormalities (identified by macroscopic observation) were recorded. Once hatched, the hatched fry were continuously exposed at the same dose range for the additional $15 \mathrm{~d}$. The fish were observed daily. All dead fish were removed and recorded. After the additional $15 \mathrm{~d}$ of exposure, the genetic sex ratio was counted simply by the color of the fish. In the d-rR strain of medaka, sex-linked genes determine orange-red coloration in males and white color in females (Edmunds et al., 2000; Scholz and Gutzeit, 2000). The medaka (Oryzias latipes) has an XY-XX genetic sex determination system. In the $\mathrm{d}-\mathrm{rR}$ strain the genetic sex, i.e. $\mathrm{XX}$ or $\mathrm{XY}$, is phenotypically apparent since only the Y-chromosome carries an allele for the formation of orange-red chromatophores (Scholz and Gutzeit, 2000). In the present study, the color on the tails of the fish was the main criterion for determining males or females. For Japanese medaka, the male or female fish in about $15 \mathrm{~d}$ posthatch can be distinguished by color (Sun et al., 2007).

At the juvenile-adult developmental stage, experiments were divided into a continual exposure and a water recovery groups. In the continual exposure group, six females and six males were assigned randomly to a $5 \mathrm{~L}$ glass aquarium. Fish were continuously exposed to nominal E1 concentrations of 5, 50 and $500 \mathrm{ng} \mathrm{L}^{-1}$. In addition, the SC was included in the exposure experiment design. The SC aquaria and all E1 exposure aquaria received 0.1\% DMSO. In the water recovery group, six females and six males were maintained in dechlorinated tap water in a $5 \mathrm{~L}$ glass aquarium and duplicate aquaria were used. At the same time, dechlorinated tap water control (WC) was included in the water recovery experiment design. The exposure and control solutions were renewed every $24 \mathrm{~h}$. Treated and water recovery fish were continually maintained for another $60 \mathrm{~d}$.

The entire test duration was $90 \mathrm{~d}$ and the feeding regime was maintained throughout the exposure period. Feeding consisted of newly hatched brine shrimp (Artemia nauplii) for days $0-7$, and a commercial granule food and a diet supplement of dry brine shrimp from day $7+$. 


\subsection{Specimen preparation}

At the end of the exposure period, all surviving fish were frozen by keeping them on ice for 1-2 min, and the body weight was measured. Then the fish were dissected and the livers and gonads were isolated, weighed and flash-frozen in liquid nitrogen and stored at $-70{ }^{\circ} \mathrm{C}$ until analysis. The gonadosomatic index (GSI, \%) was calculated as follows: GSI $=$ (weight of the gonads in $\mathrm{mg}$ ) $\times 100 /$ (weight of the total body in $\mathrm{mg}$ ). The hepatosomatic index (HSI, \%) was calculated as follows: $\mathrm{HSI}=($ weight of the liver in $\mathrm{mg}) \times 100 /($ weight of the total body in $\mathrm{mg}$ ).

\subsection{RNA isolation and real-time PCR}

Total RNA was isolated from the livers of individual male and female fish using Trizol reagent. RNA samples were treated with DNase I (Ambion, UK) to remove contaminating genomic DNA and purified by spin column (RNeasy; Qiagen) according to the manufacturer's instructions. Then the RNA samples were dissolved in ribonuclease-free water and stored at $-80^{\circ} \mathrm{C}$ until the process of reverse-transcriptase polymerase chain reaction.

The reverse transcription reaction mixtures containing $10 \mu \mathrm{L}$ of total RNA, $2 \mu \mathrm{L}$ of random primers, and diethyl pyrocarbonatetreated water (a total volume of $12 \mu \mathrm{L}$, were heated to $70^{\circ} \mathrm{C}$ for $5 \mathrm{~min}$ and quickly chilled on ice. After cooling, $50 \mathrm{mM}$ Tris- $\mathrm{HCl}$ buffer (pH 8.3), $75 \mathrm{mM} \mathrm{KCl}, 10 \mathrm{mM}$ dithiothreitol, $3 \mathrm{mM} \mathrm{MgCl}$, $2 \mathrm{mM}$ deoxynucleotide triphosphate $(10 \mathrm{mM}$ each), 40 units of RNAasin (RNAase inhibitor; Promega), and $200 \mathrm{U}$ of Moloney Murine Leukemia Virus Reverse Transcriptase (Promega) were added to a total volume of $25 \mu \mathrm{L}$ and incubated for $1 \mathrm{~h}$ at $37^{\circ} \mathrm{C}$. Thereafter, the reaction mixture was heated to $70^{\circ} \mathrm{C}$ for $10 \mathrm{~min}$ to inactivate the reverse transcription.

Real-time PCR was performed in MX3005P real-time quantitative polymerase chain reaction system (Stratagene, USA) in a total volume of $25 \mu \mathrm{L}$, consisting of the Brilliant II Sybr Green QPCR master mix, $300 \mathrm{nmol} \mathrm{L}^{-1}$ each of forward and reverse primers. The thermal cycle parameters used were: $10 \mathrm{~min}$ at $95^{\circ} \mathrm{C}, 1 \mathrm{~min}$ $57{ }^{\circ} \mathrm{C}$ and $30 \mathrm{~s}$ at $72{ }^{\circ} \mathrm{C}$. All the samples were analyzed in triplicate and the mean value of these triplicate measurements were used for calculations of mRNA expressions. Results were analyzed according to delta-delta Ct method. The primers of ER $\alpha$ and VTG-I genes were reported by Zhang and $\mathrm{Hu}$ (2008). The housekeeping gene $\beta$-action was used as the internal standard when performing gene expression analysis (Zhang et al., 2008a). The ER $\alpha$ and Vtg-I m RNA expressions were normalized for $\beta$-action mRNA expression. Dissociation curve analysis was performed for each gene to check the amplification of untargeted fragments. Only one peak was observed for each amplification, indicative for the amplification of the target gene only. Gene expression data are presented as changed relative to control animals within the same treatment period.

\subsection{Statistical analysis}

All statistical analyses were completed by using SPSS 13.0 (SPSS, Chicago, IL, USA) and Origin 8.0 (OriginLab, Northampton, MA, USA). The experimental data were checked for assumptions of normality using Kolmogorov-Smirnov one-sample test and Shapiro-Wilk test. When the assumptions were met, the data were subjected to one-way analysis of variance (ANOVA) with specific means comparisons by Dunnett's test. When data failed either test, the nonparametric Kruskal-Wallis test was used. In order to avoid biases associated with size-specific indices (Packard and Boardman, 1999; Kang et al., 2002), analysis of covariance (ANCOVA) with body weight of medaka as a covariate was used to compare the GSI and HSI among all experimental groups. The critical values for statistical significance were $p \leqslant 0.05$ or $p \leqslant 0.01$.

\section{Results}

\subsection{Effects on the embryonic development and sex ratio of medaka}

Less than $4 \mathrm{~h}$ post-fertilization embryos were exposed continuously to E1 for $15 \mathrm{~d}$ through the major embryonic stages (blastula, gastrula, neurula and organogenesis), hatching, and into the larval stage. Compared with the SC, E1 at $50 \mathrm{ng} \mathrm{L}^{-1}$ and above significantly lowered the hatchability $(p \leqslant 0.025)$ and lengthened the time to hatch of the fertilized eggs $(p \leqslant 0.038)$. At the same time, at E1 concentrations greater than $50 \mathrm{ng} \mathrm{L}^{-1}$, gross abnormalities in the exposure groups were also significantly increased relative to the SC ( $p=0.033$ at $500 \mathrm{ng} \mathrm{L}^{-1} ; p=0.008$ at $\left.5000 \mathrm{ng} \mathrm{L}^{-1}\right)$. The two most common features for gross abnormalities in larvae were scoliosis and abdominal swelling.

After the additional $15 \mathrm{~d}$ of exposure, the males and females were identified by the color of the fish. The female: male ratio in all treatment groups was higher than that in the SC groups, and females were about three times as numerous as males at $5000 \mathrm{ng} \mathrm{L}^{-1}$ E1 (Table 1).

\subsection{Tissue somatic indices}

The effects of a further $60 \mathrm{~d}$ exposure to E1 on the HSI and GSI in male and female medaka are shown in Fig. 1. Compared with the SC, a significant decrease in the HSI in males was found at $500 \mathrm{ng} \mathrm{L}^{-1} \mathrm{E} 1 \quad(p=0.043)$, while the HSI in females showed no significant differences between the SC and the E1 groups. When exposed to $500 \mathrm{ng} \mathrm{L}^{-1} \mathrm{E} 1$, this led to a marked decrease in the female GSI $(p=0.017)$, whereas there was a significant increase in the male GSI at all E1 exposures $\left(p<0.001\right.$ at 5 and $50 \mathrm{ng} \mathrm{L}^{-1}$, and $p=0.034$ at $500 \mathrm{ng} \mathrm{L}^{-1}$ ). The sex reversal of male fish was identified by autopsy. The males which had a red color on the tail and a mature ovary were identified as sex reversal fish. We noted sex reversal in all males treated with 5 and $50 \mathrm{ng} \mathrm{L}^{-1} \mathrm{E} 1$ at the end of the $90 \mathrm{~d}$ exposure period (Table 2). Three of six males were found to have sex reversal at $500 \mathrm{ng} \mathrm{L}^{-1} \mathrm{E} 1$. The other three males at $500 \mathrm{ng} \mathrm{L}^{-1} \mathrm{E} 1$ were abnormal with abdominal swelling and their testis or ovary could not be recognized by macroscopic observation. The ovaries of five females treated with $500 \mathrm{ng} \mathrm{L}^{-1}$ were degenerated. In addition, mortality was also found in the highest exposure group ( $500 \mathrm{ng} \mathrm{L}^{-1}$ ). At $500 \mathrm{ng} \mathrm{L}^{-1} \mathrm{E} 1$, only nine medaka survived to the end of the exposure period, and one female and two males died. In these died fish, one female and one male were abnormal. At the same time, in all of the surviving fish, six fish including four females and two males were abnormal. One of the most common abnormalities was abdominal swelling.

Fig. 2 shows the HSI and GSI of males and females that were developed from post-fertilization and hatched fry were exposed to E1 at the concentrations of $5,50,500$ and $5000 \mathrm{ng} \mathrm{L}^{-1}$ for $30 \mathrm{~d}$, followed by maintenance of the hatched fry in dechlorinated tap water to the end of experiment. The HSI in the males and females showed no significant differences between the WC group and E1 groups. A significant decrease of the female GSI was observed at concentrations higher than $50 \mathrm{ng} \mathrm{L}^{-1} \mathrm{E} 1$ relative to the WC ( $p \leqslant 0.032)$, whereas there was a significant increase of the male GSI in all E1 groups $(p \leqslant 0.026)$. Sex reversal was also observed in all E1 groups. However, the percent of male sex reversals in the water recovery groups was lower than those in the $90 \mathrm{~d}$ exposure groups (Table 2). Sex reversal was noted about 50\% and $58 \%$ of male fish treated with 5 and $50 \mathrm{ng} \mathrm{L}^{-1}$ of E1, respectively. This increased to about $70 \%$ and $90 \%$ of males at 500 and $5000 \mathrm{ng} \mathrm{L}^{-1}$, respectively. No mortality or obvious abnormalities were observed at the end of the experiment in the water recovery groups. 
Table 1

Hatchability, time to hatching, gross abnormalities rate of fertilized eggs exposed to E1 for $15 \mathrm{~d}$ and sex ratio of the fish after the additional $15 \mathrm{~d}$ of exposure.

\begin{tabular}{|c|c|c|c|c|}
\hline $\mathrm{E} 1\left(\mathrm{ng} \mathrm{L}^{-1}\right)$ & Hatchability (\%) (hatched fish number) & Time to hatching $(\mathrm{d})$ & Gross abnormality rate (\%) (abnormality number) & Sex ratio (female:male) \\
\hline SC & $94.4 \pm 1.92(170)$ & $11.7 \pm 0.58$ & $4.7 \pm 4.1(8)$ & $1.18: 1(66: 56)$ \\
\hline 5 & $85.6 \pm 6.9(154)$ & $12.3 \pm 0.58$ & $5.2 \pm 6.2(8)$ & $1.42: 1(68: 48)$ \\
\hline 50 & $86.7 \pm 3.3^{*}(156)(p=0.025)$ & $12.7 \pm 1.15^{*}(p=0.038)$ & $8.9 \pm 1.9(14)$ & $1.55: 1(62: 40)$ \\
\hline 500 & $72.2 \pm 7.7^{* *}(130)(p=0.001)$ & $13.7 \pm 0.58^{*}(p=0.014)$ & $16.6 \pm 5.6^{*}(22)(p=0.033)$ & $1.65: 1(56: 34)$ \\
\hline 5000 & $68.9 \pm 8.4^{* *}(124)(p<0.001)$ & $14 \pm 1.73^{* *}(p=0.002)$ & $20.6 \pm 11.4^{* *}(26)(p=0.008)$ & $2.73: 1(60: 22)$ \\
\hline
\end{tabular}

The asterisks $\left({ }^{*}\right)$ and $\left({ }^{* *}\right)$ denote statistically significant difference compared with the solvent control $(\mathrm{SC})(p<0.05 ; p<0.01)$, respectively.
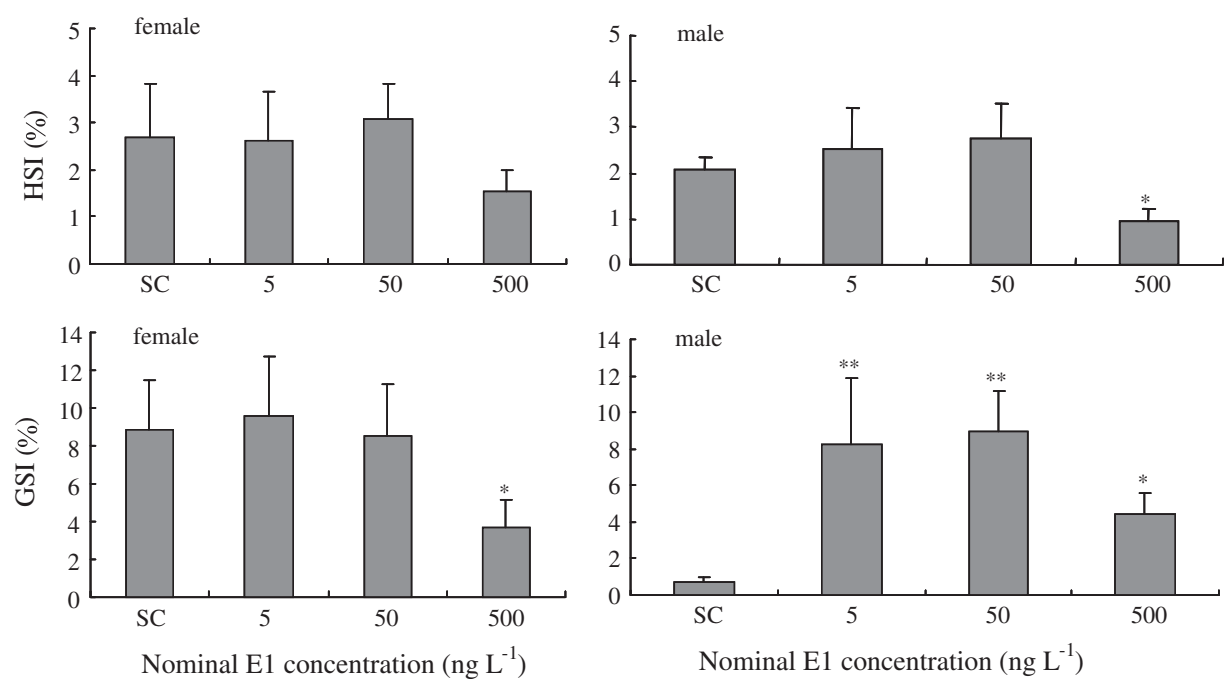

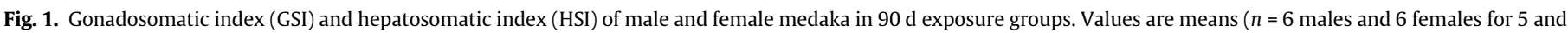

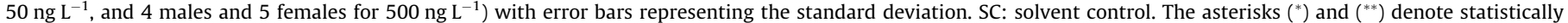
significant difference compared with the solvent control $(p<0.05 ; p<0.01)$, respectively.

Table 2

Effect of E1 on survival, abnormality and sex reversal of medaka.

\begin{tabular}{|c|c|c|c|c|c|c|}
\hline & $\mathrm{E} 1\left(\mathrm{ng} \mathrm{L}^{-1}\right)$ & Exposed females/males & Surviving females/males & Abnormality females/males & Females & Sex reversal males \\
\hline \multirow[t]{4}{*}{ A } & SC & $6 / 6$ & $6 / 6$ & $0 / 0$ & 6 & 0 \\
\hline & 5 & $6 / 6$ & $6 / 6$ & $0 / 0$ & 6 & 6 \\
\hline & 50 & $6 / 6$ & $6 / 6$ & $0 / 0$ & 6 & 6 \\
\hline & 500 & $6 / 6$ & $5 / 4$ & $5 / 3$ & 6 & 3 \\
\hline \multirow[t]{5}{*}{ B } & WC & $12 / 12$ & $12 / 12$ & $0 / 0$ & 12 & 0 \\
\hline & 5 & $12 / 12$ & $12 / 12$ & $0 / 0$ & 12 & 6 \\
\hline & 50 & $12 / 12$ & $12 / 12$ & $0 / 0$ & 12 & 7 \\
\hline & 500 & $12 / 12$ & $12 / 12$ & $0 / 0$ & 12 & 9 \\
\hline & 5000 & $12 / 12$ & $12 / 12$ & $0 / 0$ & 12 & 11 \\
\hline
\end{tabular}

E1: estrone; SC: solvent control; WC: water control; A: another $60 \mathrm{~d}$ continual exposure of E1, B: $60 \mathrm{~d}$ water recovery.

\subsection{Quantification of ER and Vtg by real-time PCR}

The ER $\alpha$ and Vtg-I gene mRNA levels in medaka exposed to the SC and E1 treatments including 5 and $50 \mathrm{ng} \mathrm{L}^{-1}$ in the preliminary experiments are presented in Fig. 3. Because only nine fish survived to the end of the exposure period at the highest concentration (500 ng L $\mathrm{L}^{-1}$ ) and six of the surviving fish were abnormal, the $\mathrm{ER} \alpha$ and Vtg-I gene mRNA levels in medaka exposed to $500 \mathrm{ng} \mathrm{L}^{-1}$ were not analyzed. There was no significant difference in the ER $\alpha$ gene expression between the E1 treatments and the SC. For the female and male fish, Vtg-I gene mRNA levels showed different change trends. In all E1 treatment groups, a significant up-regulation of the Vtg-I gene expression was found in the males $(p<0.001)$. In contrast, in the females, down-regulated expression of the Vtg-I gene was found at $50 \mathrm{ng} \mathrm{L}^{-1}(p=0.036)$.
The ER $\alpha$ and Vtg-I gene mRNA levels in the water recovery group medaka are presented in Fig. 4. In the male medaka, all concentrations of E1 caused a significant increase in the Vtg-I gene mRNA levels $(p \leqslant 0.027)$ that was dose-dependent. In contrast, the Vtg-I gene mRNA levels of females decreased significantly at $500 \mathrm{ng} \mathrm{L}^{-1} \mathrm{E} 1(p=0.015)$, and no significant difference was found between the WC and other E1 groups. There was no significant difference in the expressions of the ER $\alpha$ gene in males and females between the E1 treatments and the WC.

\section{Discussion}

At E1 concentrations of $50 \mathrm{ng} \mathrm{L}^{-1}$ or above, adverse effects on hatchability time to hatching were observed, and a significantly high gross abnormality rate in medaka was found at $500 \mathrm{ng} \mathrm{L}^{-1}$ 

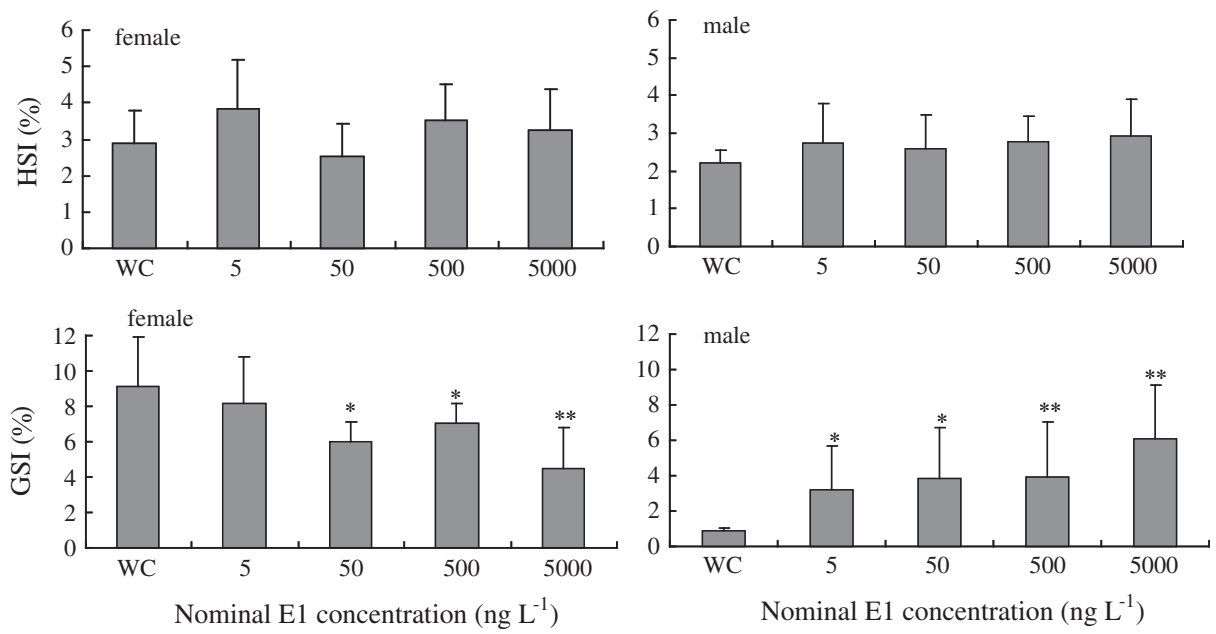

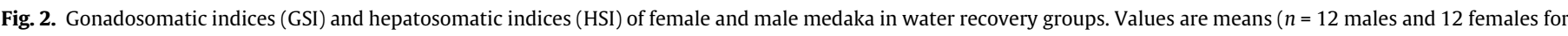

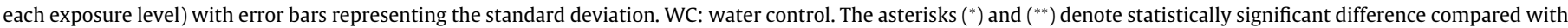
the water control $(p<0.05 ; p<0.01)$, respectively.
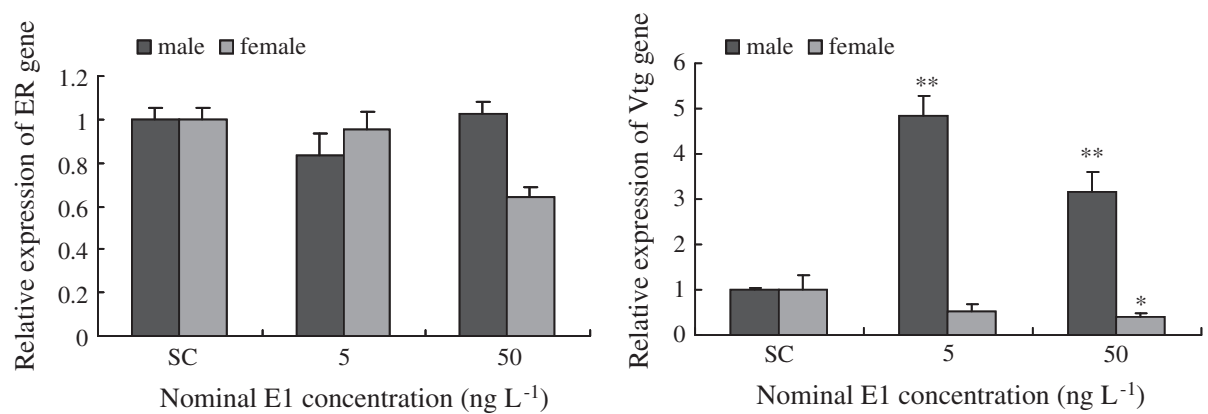

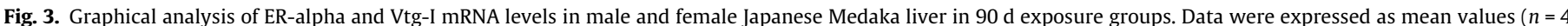

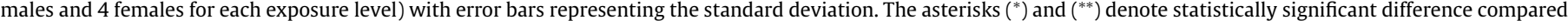
with the solvent control $(p<0.05 ; p<0.01)$, respectively.
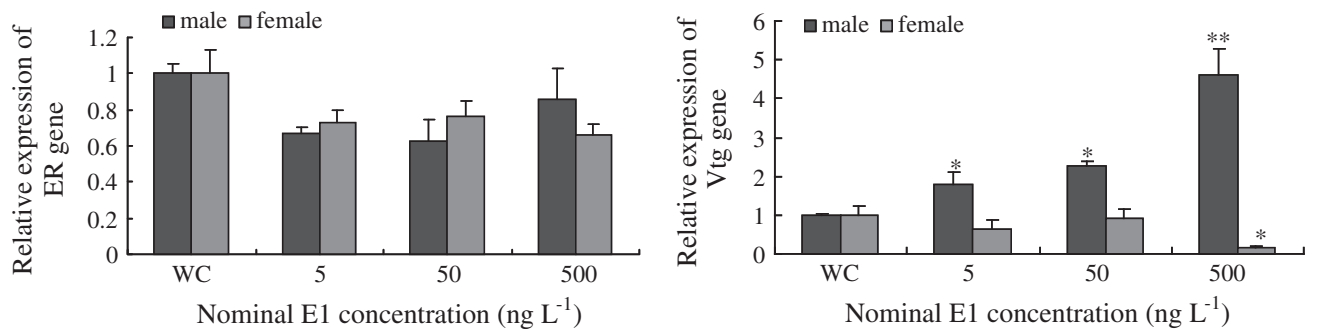

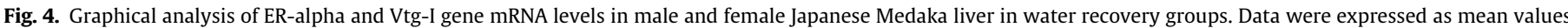

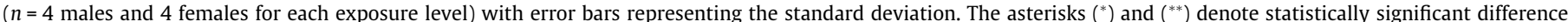
compared with the water control $(p<0.05 ; p<0.01)$, respectively.

and $5000 \mathrm{ng} \mathrm{L}^{-1} \mathrm{E} 1$ (Table 1$)$. E1 has a lipophilicity $\log k_{\text {ow }}$ estimated to be 3.1 (Liscio et al., 2009) which can partition into lipid compartments (e.g. membranes). Therefore, it would be expected that E1 can transfer from water into the developing embryo during exposure time and interfere with normal embryonic development and the hatching process. Lee et al. (2012) reported that the three xenoestrogens of nonylphenol (NP), E2 and bisphenol A (BPA) can retard the embryonic development and lengthen the time to hatch of the transgenic medaka embryos. A sex ratio of female: male at $5 \mathrm{ng} \mathrm{L}^{-1} \mathrm{E} 1$ or above was higher than that at SC group (Table 1). Estrogens are active at sex steroid receptors and theoretically possess the potential to alter normal sexual differentiation in amphibians or fish to produce more females. Some studies have reported that fish or amphibans exposed to estrogens can cause female-biased phenotypic sex-ratios (Pettersson et al., 2006; Zha et al., 2008; Chu et al., 2011). However, to our knowledge, only one paper has reported the alteration of genotypic sex ratio in fish exposed to tamoxifen (Sun et al., 2007). In the present study, E1 at concentrations of 5 and $50 \mathrm{ng} \mathrm{L}^{-1}$ resulted in the death of more than $14 \%$ of embryos. This death increased to about $28 \%$ and $31 \%$ of embryos at 500 and $5000 \mathrm{ng} \mathrm{L}^{-1}$, respectively. The observed change in sex ratio may have been caused by differential sensitivity of the embryos (i.e. the embryo with the XY chromosome may be more sensitive to E1 than the embryo carrying the 
$\mathrm{XX}$ chromosome) resulting in more dead embryos with the $\mathrm{XY}$ chromosome. The specific reasons for the change in sex ratio require future study.

Some endpoints such as GSI and HSI are a general measure of the growth status of specific fish tissues. The GSI of males increased significantly at any E1 treatment in both continual exposure group and water recovery group, and in the water recovery group the increase was dose-dependent relative to the water control. The high GSI of males might be due to sex inversions. In both continual exposure group and water recovery group, the phenomena of sex reversal of males were all found. Sex inversions in fish exposed to endocrine-disrupting chemicals (EDCs) have been reported previously and may involve estrogenic chemicals eliciting female characteristics in males, or androgenic chemicals producing male traits in females (Edmunds et al., 2000; Iwamatsu et al., 2000; Sun et al., 2007). The GSI of females decreased significantly at $500 \mathrm{ng} \mathrm{L}^{-1} \mathrm{E} 1$ in the continual exposure group. The low GSI of females might be due to degeneration of the ovary (Scholz and Gutzeit, 2000; Zhang et al., 2008a). Seki et al. (2002) reported regression of ovaries in adult female medaka exposed to $488 \mathrm{ng} \mathrm{L}^{-1}$ estrogen EE2 for three weeks. Decreased GSI was also observed in female rare minnows exposed to EE2 (Zha et al., 2008) and 4-NP, 2,4-dichlorophenol (2,4-DCP) (Zhang et al., 2008a,b). However, the GSI of females decreased significantly at $50 \mathrm{ng} \mathrm{L}^{-1} \mathrm{E} 1$ or above in the water recovery group which indicated that although obvious ovarian degeneration of the females were not found by macroscopic observation, normal ovary growth and development of the females were affected when the early life stages of the fish were exposed to E1. These results showed that E1 could alter the normal GSI levels of medaka, and even if medaka were only exposed to E1 during their early life stages, the alteration is still unrecoverable.

Vtg is an egg yolk precursor protein that is synthesized primarily in the liver of females, and its expression is normally dormant in males (Matozzo et al., 2008). However, it can be activated and regulated in males by exposure to estrogenic substances (Mitsui et al., 2007; Caldwell et al., 2008, 2012). Therefore, the Vtg gene in male fish is generally accepted as a suitable biomarker for estrogenic exposure and this is confirmed for E1 from this study. The fact that all concentrations of E1 significantly up-regulated Vtg gene expression in the males indicates that the threshold is lower than $5 \mathrm{ng} \mathrm{L}^{-1}$. In the continual exposure groups and water recovery groups, the expressions of the hepatic estrogen receptor $\alpha$ (ER $\alpha)$ gene were not significantly different between all E1 treatments and controls. ER $\alpha$ is auto-regulated by the presence of estrogen response elements (EREs) and expressed in many tissues of fish species. Previous work showed that ER could act as the transcription repression factor (An et al., 1999), which could inhibit Vtg mRNA expression and downstream Vtg protein synthesis in female fish. Other studies reported that liver vitellogenin and ER $\alpha$ mRNA levels increased simultaneously after estrogen compound treatment in fish (Atteke et al., 2003; Andreassen et al., 2005). Flouriot et al. (1997) also considered that the up-regulation of Vtg mRNA depends directly on the number of estrogen receptors, which are also regulated at the mRNA level by estrogen treatment in fish. However, in this study, we noted profound decreases in the hepatic Vtg mRNA in female medaka treated with E1. The mechanism by which E1 down-regulates Vtg proteins in females and up-regulates Vtg proteins in males is not known but could involve both competition and synthesis of specific mRNAs. Presumably E1 competes with endogenous E2 for ER down-regulating Vtg transcription in females, but stimulates the male receptor leading to transcriptional events and Vtg synthesis. However, it is important to bear in mind that the ER-mediated pathway is regulated by many other factors including co-activators and co-repressors, and by phosphorylations and interaction with other signaling pathways (Andreassen et al., 2005). The results of this study are consistent with those of the other studies which reported that the up-regulation of hepatic Vtg mRNA was observed in male fish exposed to estrogen compounds like E2, but there was no significant difference in the expression level of hepatic ER mRNA (Arukwe et al., 2001; Boyce-Derricott et al., 2009).

This study evaluated the effects of E1 on the early life stages and gene mRNA levels of Japanese medaka after exposure during the embryonic, larval, juvenile, and adult-life stages. At the same time, a water recovery experiment was set up to assess the effects of exposure of E1 in the early life stages on growth and reproduction of the fish. Under the conditions of these experiments, E1 altered the Vtg gene expression of both sexes, and affected normal gonad growth and development. Even if only early life stages were exposed to E1, the adverse effects on medaka fish were still unrecoverable. In particular, the change in sex ratio and sex reversal of the fish is noteworthy and deserves more study in the future.

\section{Conclusions}

E1 has been detected at about 1-10 $\mathrm{ng} \mathrm{L}^{-1}$ levels in many water bodies. But, even at such level, this study showed that E1 could have adverse impacts on the embryonic development, sex differentiation, normal gonad growth and Vtg-I gene expression of medaka. In addition, exposure to E1 altered the normal sex ratio and resulted in sex reversal in male fish. Even if only the early life stages were exposed to E1, these adverse effects on medaka were still inevitable.

\section{Acknowledgements}

We gratefully acknowledge the supports of Shanghai Leading Academic Discipline (Grant No. S30109), the Outstanding Young Teacher Research and Special Projects (Grant No. shu10040).

\section{References}

An, J., Ribeiro, R.C., Webb, P., Gustafsson, J.A., Kushner, P.J., Baxter, J.D., Leitman, D.C., 1999. Estradiol repression of tumor necrosis factor-alpha transcription requires estrogen receptor activation function-2 and is enhanced by coactivators. Proc. Natl. Acad. Sci. USA 96, 15161-15166.

Andreassen, T.K., Skjoedt, K., Korsgaard, B., 2005. Upregulation of estrogen receptor $\alpha$ and vitellogenin in eelpout (Zoarces viviparous) by waterborne exposure to 4tert-octylphenol and 17 $\beta$-estrodiol. Comp. Biochem. Physiol. Part C 140, 340346.

Arukwe, A., Kullman, S.W., Hinton, D.E., 2001. Differential biomarker gene and protein expressions in nonylphenol and estradiol-17 $\beta$ treated juvenile rainbow trout (Oncorhynchus mykiss). Comp. Biochem. Physiol. Part C 129, 1-10.

Atteke, C., Vetillard, A., Fostier, A., Garnier, D.H., Jego, P., Bailhache, T., 2003. Effect of progesterone and estradiol on the reproductive axis in immature diploid and triploid rainbow trout. Comp. Biochem. Physiol. Part A 134, 693-705.

Boyce-Derricott, J., Nagler, J.J., Cloud, J.G., 2009. Regulation of hepatic estrogen receptor isoform mRNA expression in rainbow trout (Oncorhynchus mykiss). Gen. Comp. Endocr. 161, 73-78.

Caldwell, D.J., Mastrocco, F., Anderson, P.D., Länge, R., Sumpter, J.P., 2012. Predictedno-effect concentrations for the steroid estrogens estrone, $17 \beta$-estradiol, estriol, and $17 \alpha$-ethinylestradiol. Environ. Toxicol. Chem. 31 (6), 1396-1406.

Caldwell, D.J., Mastrocco, F., Hutchinson, T.H., Länge, R., Heijerick, D., Janssen, C., 2008. Derivation of an aquatic predicted no-effect concentrations for the synthetic hormone, 17 $\alpha$-ethinylestradiol. Environ. Sci. Technol. 42, 7046-7054.

Cargouët, M., Perdiz, D., Mouatassim-Souali, A., Tamisier-Karolak, S., Levi, Y., 2004 Assessment of river contamination by estrogenic compounds in Paris area (France). Sci. Total Environ. 324, 55-66.

Chu, Z.J., Wu, Y.X., Gong, S.Y., Zhang, G.B., Zhang, L., Yuan, Y.C., Yuan, H.W., 2011. Effects of estradiol valerate on steroid hormones and sex reversal of female rice field eel, Monopterus albus (Zuiew). J. World Aquacult. Soc. 42 (1), 96-104.

Collucci, M.S., Topp, E., 2001. Dissipation of part-per-trillion concentrations of estrogenic hormones from agricultural soils. Can. J. Soil Sci. 82, 335-340.

Dammann, A.A., Shappell, N.W., Bartell, S.E., Schoenfuss, H.L., 2011. Comparing biological effects and potencies of estrone and $17 \beta$-estradiol on mature fathead minnows, Pimephales promelas. Aquat. Toxicol. 105, 559-568.

Edmunds, J.S., McCarthy, R.A., Ramsdell, J.S., 2000. Permanent and functional male to female sex reversal in d-rR strain medaka (Oryzias latipes) following egg microinjection of o, p'-DDT. Environ. Health Perspect. 108, 219-224. 
Flouriot, G., Pakdel, F., Ducouret, B., Ledrean, Y., Valotaire, Y., 1997. Differential regulation of two genes implicated in fish reproduction: vitellogenin and estrogen receptor genes. Mol. Reprod. Dev. 48, 317-323.

Hanselman, T.A., Graetz, D.A., Wilkie, A.C., 2003. Manure-borne estrogens as potential environmental contaminants: a review. Environ. Sci. Technol. 37, 5471-5478.

Hintemann, T., Schneider, C., Schöler, H.F., Schneider, R.J., 2006. Field study using two immunoassays for the determination of estradiol and ethinylestradiol in the aquatic environment. Water Res. 40, 2287-2294.

Hyndman, K.M., Biales, A., Bartell, S.E., Schoenfuss, H.L., 2010. Assessing the effects of exposure timing on biomarker expression using $17 \beta$-estradiol. Aquat. Toxicol. 96, 264-272.

Imai, S., koyama, J., Fuji, k., 2007. Effects of estrone on full life cycle of Java medaka (Oryzias Javanicus), a new marine test fish. Environ. Toxicol. Chem. 26, 726-731.

Iwamatsu, T., Kobayashi, H., Hamaguchi, S., Sagegami, R., Shuo, T., 2000. Sex reversal of medaka (Oryzias latipes) by a short exposure of embryos to sex steroids. Zool. Sci. $17,15-28$

Jobling, S., Tyler, C.R., 2003. Endocrine disruption in wild freshwater fish. Pure Appl. Chem. 75, 2219-2234

Kang, I.J., Yokota, H., Oshima, Y., Tsuruda, Y., Oe, T., Imada, N., Tadokoro, H., Honjo, T., 2002. Effects of bisphenol A on the reproduction of Japanese medaka (Oryzias latipes). Environ. Toxicol. Chem. 21, 2394-2400.

Kidd, K.A., Blanchfield, P.J., Mills, K.H., Palace, V.P., Evans, R.E., Lazorchak, J.M., Flick, R.W., 2007. Collapse of a fish population after exposure to a synthetic estrogen. Proc. Natl. Acad. Sci. USA 104, 8897-8901.

Kuster, M., López de Alda, M.J., Barceló, D., 2004. Analysis and distribution of estrogens and progestogens in sewage sludge, soils and sediments. Trend. Anal. Chem. 23, 790-798.

Lange, A., Paull, G.C., Hamilton, P.B., Iguchi, T., Tyler, C.R., 2011. Implications of persistent exposure to treated wastewater effluent for breeding in wild roach (Rutilus rutilus) populations. Environ. Sci. Technol. 45, 1673-1679.

Lee, W., Kang, C.W., Su, C.K., Okubo, K., Nagahama, Y., 2012. Screening estrogenic activity of environmental contaminants and water samples using a transgenic medaka embryo bioassay. Chemosphere 88, 945-952.

Lei, B.L., Huang, S.B., Zhou, Y.Q., Wang, D.H., Wang, Z.J., 2009. Levels of six estrogens in water and sediment from three rivers in Tianjin area, China. Chemosphere 76 36-42.

Liscio, C., Magi, E., Di Carro, M., Suter, M.J.F., Vermeirssen, E.L.M., 2009. Combining passive samplers and biomonitors to evaluate endocrine disrupting compounds in a wastewater treatment plant by LC/MS/MS and bioassay analyses. Environ. Pollut. 157, 2716-2721.

Lu, G.H., Yan, Z.H., Wang, Y.H., Chen, W., 2011. Assessment of estrogenic contamination and biological effects in Lake Taihu. Ecotoxicology 20, 974-981.

Lucas, S.D., Jones, D.L., 2006. Biodegradation of estrone and 17 $\beta$-estradiol in grassland soils amended with animal wastes. Soil Biol. Biochem. 38, 2803-2815.

Marking, L.L., Rach, J.J., Schreier, T.M., 1994. Evaluation of antifungal agents for fish culture. Progr. Fish-Cult. 56, 225-231.

Matozzo, V., Gagné, F., Marin, M.G., Ricciardi, F., Blaise, C., 2008. Vitellogenin as a biomarker of exposure to estrogenic compounds in aquatic invertebrates: a review. Environ. Int. 34, 531-545.

Mitsui, N., Tooi, O., Kawahara, A., 2007. Vitellogenin-inducing activities of natural, synthetic, and environmental estrogens in primary cultured Xenopus laevis hepatocytes. Comp. Biochem. Physiol. Part C 146, 581-587.

Noppe, H., Verslycke, T., De Wulf, E., Verheyden, K., Monteyne, E., Van Caeter, P., Janssen, C.R., De Brabander, H.F., 2007. Occurrence of estrogens in the Scheldt estuary: a 2-year survey. Ecotox. Environ. Safe. 66, 1-8.

Packard, G.C., Boardman, T.J., 1999. The use of percentages and size-specific indices to normalize physiological data for variation in body size: wasted time, wasted effort? Comp. Biochem. Phys. Part A 122, 37-44.
Palace, V.P., Evans, R.E., Wautier, K.G., Mills, K.H., Blanchfield, P.J., Park, B.J., Baron, C.L., Kidd, K.A., 2009. Interspecies differences in biochemical, histopathological, and population responses in four wild fish species exposed to ethynylestradiol added to a whole lake. Can. J. Fish. Aquat. Sci. 66, 1920-1935.

Panter, G.H., Thompson, R.S., Sumpter, J.P. 1998. Adverse reproductive effects in male fathead minnows (Pimephales promelas) exposed to environmentally relevant concentrations of the natural oestrogens, oestradiol and oestrone. Aquat. Toxicol. 42, 243-353.

Pettersson, I., Arukweb, A., Lundstedt-Enkel, K., Mortensen, A.S., Berg, C., 2006 Persistent sex-reversal and oviducal agenesis in adult Xenopus (Silurana) tropicalis frogs following larval exposure to the environmental pollutant ethynylestradiol. Aquat. Toxicol. 79, 356-365.

Randak, T., Zlabek, V., Pulkrabova, J., Kolarova, J., Kroupova, H., Siroka, Z., Velisek, J. Svobodova, Z., Hajslova, J., 2009. Effects of pollution on chub in the River Elbe Czech Republic. Ecotox. Environ. Saf. 72, 737-746.

Scholz, S., Gutzeit, H.O., 2000. 17-alpha-ethinylestradiol affects reproduction, sexua differentiation and aromatase gene expression of the medaka (Oryzias latipes). Aquat. Toxicol. 50, 363-373.

Seki, M., Yokota, H., Matsubara, H., Tsuruda, Y, Maeda, M., Tadokoro, H., Kobayashi, K., 2002. Effect of ethinylestradiol on the reproduction and induction of vitellogenin and testis-ova in medaka (Oryzias latipes). Environ. Toxicol. Chem. 21, 1692-1698.

Stumpe, B., Marschner, B., 2009. Factors controlling the biodegradation of $17 \beta$ estradiol, estrone and $17 \alpha$-ethinylestradiol in different natural soils. Chemosphere 74, 556-562.

Sun, L.W., Zha, J.M., Spear, P.A., Wang, Z.J., 2007. Tamoxifen effects on the early life stages and reproduction of Japanese medaka (Oryzias Latipes). Environ. Toxicol. Pharm. 24, 23-29.

Sun, L.W., Zha, J.M., Wang, Z.J., 2009. Interactions between estrogenic chemicals in binary mixtures investigated using vitellogenin induction and factorial analysis. Chemosphere 75, 410-415.

Van den Belt, K., Berckmans, P., Vangenechten, C., Verheyen, R., Witters, H., 2004 Comparative study on the in vitro/in vivo estrogenic potencies of $17 \beta$-estradiol, estrone, 17 $\alpha$-ethynylestradiol and nonylphenol. Aquat. Toxicol. 66, 183-195.

Vethaak, A.D., Lahr, J., Schrap, S.M., Belfroid, A.C., Rijs, G.B.J., Gerritsen, A., de Boer, J. Bulder, A.S., Grinwis, G.C.M., Kuiper, R.V., Legler, J., Murk, T.A.J., Peijnenburg, W. Verhaar, H.J.M., de Voogt, P., 2005. An integrated assessment of estrogenic contamination and biological effects in the aquatic environment of the Netherlands. Chemosphere 59, 511-524.

Williams, R. J. Johnson, A.C., Smith, J.J.L., Kanda, R., 2003. Steroid estrogens profiles along river stretches arising from sewage treatment works discharges. Environ. Sci. Technol. 37, 1744-1750.

Zha, J., Sun, L., Zhou, Y., Spear, P., Ma, M., Wang, Z., 2008. Assessment of 17aethinylestradiol effects and underlying mechanisms in a continuous, multigeneration exposure of the Chinese rare minnow (Gobiocypris rarus) Toxicol. Appl. Pharm. 226, 298-308.

Zhang X.Y, Zha, J.M. Li, W. Yang, L.H. Wang, ZJ, 2008a. Effects of 2,4 dichlorophenol on the expression of vitellogenin and estrogen receptor genes and physiology impairments in Chinese rare Minnow (Gobiocypris rarus). Environ. Toxicol. 23 (6), 694-701.

Zhang, X.Y., Zha, J.M., Wang, Z.J., 2008b. Influences of 4-nonylphenol on doublesexand mab-3-related transcription factor 1 gene expression and vitellogenin mRNA induction of adult rare minnow (Gobiocypris rarus). Envrion. Toxicol. Chem. 27 (1), 196-205.

Zhang, Z.B., Hu, J.Y., 2008. Effects of p, p'-DDE exposure on gonadal development and gene expression in Japanese medaka (Oryzias latipes). J. Environ. Sci. 20, 347-352. 